\title{
Clinical Reasoning: Instrument for Clinical Decisions of Nursing Students in the Care Process
}

Vinicius Lino de Souza Neto1, Ana Karoline Cordeiro Batista², Ellen Caroline Paiva Godoy², Ericka Suellen Villar², Fabrina Rafaela Birth Andrade ${ }^{2}$, Felype Joseh de Souza Lima Alves and Silva ${ }^{2}$, Fernanda Nahara Carvalho Dossantos ${ }^{2}$, Fernanda Rafaela Santos ${ }^{2}$, Isabella Kilia Macedo Silva ${ }^{2}$, Izabelle Bezerra Costa2 , Leticia Alves de Amorim², Marianna Dayenne Batista de Paiva², Michael Pyerre Martins Duarte ${ }^{2}$, Olga Alice Alencar Moreira², Thais Monteiro da Silva Padilha², Anne Heloyse Ribeiro Ferreira ${ }^{2}$, Sidcléia kecia Vieira Silva ${ }^{2}$, Kátia Regina Barros Ribeiro", Ana Elza Oliveira Mendonça1, Rosangela Vidal de Negreiros ${ }^{3}$, Mary Luce Melquiades Meira ${ }^{3}$

\section{Abstract}

Objective: Report the experience of Nursing graduation students regarding high technological density services, using the clinical reasoning practice as a tool in the care process.

Method: It is a descriptive study whose type is experience report of nursing students from a public University, located on Northeast of Brazil, that highlights the practical activities accomplished during the period of May, 23 to June, 13 of 2016.

Results: The experience provided relevant results for the nursing students during the practical activities, being structured on the following axes: nurse's work process; developed activities; and practical training.

Conclusion: The experience lived by the nursing students was typified as a tool that increases and evaluates the several abilities and skills that the nursing professional must have. And the clinical reasoning practices directs to actions and interventions of nursing increasingly safe and scientific.

\section{Introduction}

Currently, one notices that the new prevailing assistance is composed by several aspects, for instance, the technology, being mild, median or tough. The use of those technologies contributes to a

1 Professor of Nursing Graduation of Universidade Federal do Rio Grande do Norte (UFRN). Natal/RN, Brazil.

2 Nursing student of Universidade Federal do Rio Grande do Norte (UFRN). Member of the Study Group and hands-on assistance research and Epidemiological in Health and Nursing, APEHN.

3 Professor of Nursing Graduation of Universidade Federal de Campina Grande (UFCG). Campina Grande/PB, Brazil.

Contact information:

Lino Vinicius de Souza Neto.

Address: Federal University of Rio Grande do Norte. Health Sciences Centre, Department of nursing. Campus Central, s/n, Lagoa Nova. 59078-970 Natal, RN.

Đ vinolino@hotmail.com

Keywords

Nursing; Education, Nursing; Thinking; Teaching. 
more qualified and systemic assistance, however, sometimes, dependent, since they can restrict the health professional to direct the care only to biological conditions, and thus, act on the dimensioning of the care process superficially, which is characterized by its clinical, human and social span [1-2].

The nurse is a transforming agent of the multidisciplinary assistance, since his work process, places him in a unique position. This aspect requires a bigger commitment with the knowledge, so it can acquire abilities and skills, and implement actions and interventions, that are more friendly, human and scientific. However, it is believed that in the formation process it is necessary to encourage the students to new challenges, such as the clinical reasoning development [3].

The clinical reasoning is typified as a tool that the nurse uses to merge nursing phenomena, analyze, propose and intervene according to the patient's primary needs. To this end, it must develop, improve the domains of their intellectual abilities, interpersonal and techniques to make compatible clinical decisions with a safe and effective practice, and capable of producing the desired health results [4].

The clinical reasoning becomes an essential element of nursing care and to solve problems, guiding itself by standards, politics and ethical codes, in addition to develop the logic, intuition and creativity, which are critical and strengthen themselves through the use of specific knowledge and clinical experience [5].

The addition and fulfilment of practical activities on academic disciplines, allows a grasp and an early contact with the experience of applying clinical reasoning, thus enabling, that, over time, even after their graduation, the professional is capable of implementing such skill with great success, making his work process more qualified [6-7].

Therefore, the study had as purpose to report the experience of the nursing graduation students about the care in Emergency Care Unit (ECU) and
Intensive Care Unit (ICU) considering the high technological density services, using the clinical reasoning practice as a tool in the care process.

\section{Method}

It is a descriptive study whose type is experience report, with emphasis in the clinical reasoning's practice. This kind of study allows the description of situations lived by the authors, with the purpose of reinforcing the deed's importance in construction and remodeling of scientific knowledge [8]. The experience reported on this study was developed by three students and two professors from the Nursing graduation of Universidade Federal do Rio Grande do Norte (UFRN), central campus, during the realization of site activities on the discipline Integral Attention to Health II: High Complexity, that composes the curriculum disciplines of the course. The activities occurred from 23 May to 13 June of 2016, on the Red Room of the Emergency Care Unit (ECU) from Cidade da Esperança and the Intensive Care Unit (ICU) from University hospital Onofre Lopes.

The Red Room from the ECU is a space with six beds, and each one has multiparametrical monitors, mechanic fans, infusion bombs, and hemodialysis service. In addition to this, the team is composed by nurses, medics, physiotherapists and nutritionists, in other words, multidisciplinary.

The ICU from the University Hospital Onofre Lopres, featured as a teaching and research institution is composed with nine bedrooms, and each room has two beds, with multiparametrical monitors, fans and a small material storage station for each room. In addition to having a multidisciplinary team, it also possesses residents in the fields of nursing, medicine, physiotherapy, nutrition and odontology.

The Emergency Care Units are structures of intermediate complexity, serving as connection between Basic Health Units (BHU) and hospital's 
urgencies, thus, compounding the Attention Network to Urgencies. With its operation that is 24 hours a day, during the seven days of the week, are responsible for solving most of the urgencies and population's emergencies, from cases such as hypertension and hyperthermia, to more severe cases. The Red Room has as purpose to stabilize patients in critical situation, so they can be sent to a hospital unit. The ICU is a hospital unit's place destined to the care and tracking of patients with severe physiological instability, and death risk, that requires technical, specialized and scientific assistance [9-10].

Therefore, the practical activities accomplished by the health professionals in the sectors with high technological densities requires a few ramifications, such as the work's specificity, professionals' broad theoretical knowledge. So, it is possible to implement adequate actions and interventions targeted to the patients' primary needs.

\section{Results}

The experience provided relevant results for the nursing students during the practical activities, being structured on the following axes: nurse's work process; developed activities; and practical training.

\section{Nurse's work process}

Significant differences were observed regarding the nurse's work process execution, between the two field of practical activities. On the ICU from the University Hospital, it was possible to perceive a more organized work process, with the defined responsibilities of the health professionals well delimited and a multi - professional interaction, showing itself able for an effective assistance to events that may arise. On this context, the nurse not only maintained his professional autonomy, but was also able to operationalize the Nursing Process, which provided a better communication with the other professionals, ensuring security and assistance quality.
Beyond that, in the hospital it is possible to count on the availability of supplies, not only on technological scope but also regarding human resources - these factors assure the effectivity on the nurse's work process development.

In the red room from ECU, a different reality was found: The nurse's work process was less defined, probably in reason of a smaller labor force availability, fact that interfered in the developed actions' effectivity. Such situation generated a smaller expressiveness on the nurse's professional work regarding the context of assistance to the severe patient. It is worth noting, that this vagueness about the work process was not an exclusive characteristic of the nursing category.

\section{Developed activities during the curriculum practices}

The activities developed by the students in practice, monitored by the professors, corroborated to an awareness of the critical thinking about the health conditions of the sectors with high technological density. The Table 1 reveals, the main procedures made by the students.

Table 1. List of accomplished procedures by nursing students in Intensive Care Unit and Emergency Care Unit, Natal, RN, Brazil, 2016.

\begin{tabular}{|c|c|}
\hline $\begin{array}{c}\text { Emergency Care Unit Red } \\
\text { Room }\end{array}$ & Intensive Care Unit \\
\hline $\begin{array}{l}\text { Decubitus' change of patient } \\
\text { in bed }\end{array}$ & $\begin{array}{l}\text { Exchange of drain bandages } \\
\text { from thorax and surgical } \\
\text { wounds }\end{array}$ \\
\hline Execution of bath in bed & $\begin{array}{l}\text { Medication preparation and } \\
\text { administration }\end{array}$ \\
\hline Cleaning of oral cavity & $\begin{array}{l}\text { Withdrawal of the peripheral } \\
\text { venous access }\end{array}$ \\
\hline $\begin{array}{l}\text { Capillary blood glucose } \\
\text { testing }\end{array}$ & Arterial blood harvesting \\
\hline Nursing process application & Suction of Air passages \\
\hline $\begin{array}{l}\text { Preparation of the body after } \\
\text { death }\end{array}$ & Medication calculations \\
\hline Passage of nasogastric probe & Hydric balance \\
\hline $\begin{array}{l}\text { Passage of probe from the } \\
\text { nose to the intestines }\end{array}$ & Checklist for shift change \\
\hline
\end{tabular}




\begin{tabular}{l|l}
\hline $\begin{array}{l}\text { Emergency Care Unit Red } \\
\text { Room }\end{array}$ & \multicolumn{1}{c}{ Intensive Care Unit } \\
\hline $\begin{array}{l}\text { Passage of delayed vesical } \\
\text { probe } \\
\text { Infusion bombs manipulation }\end{array}$ & $\begin{array}{l}\text { Reading and interpretation } \\
\text { of laboratorial exams } \\
\text { Levelling and "zeroing" of } \\
\text { invasive arterial pressure }\end{array}$ \\
\hline $\begin{array}{l}\text { Multiparametrical monitors } \\
\text { manipulation }\end{array}$ & $\begin{array}{l}\text { Participation on mini- } \\
\text { seminars about the mechanic } \\
\text { ventilation device }\end{array}$ \\
\hline Mechanic fan manipulation & $\begin{array}{l}\text { Fulfilment of evolution on } \\
\text { electronic handbooks }\end{array}$ \\
\hline
\end{tabular}

\section{Practical training}

Such practical activities allowed the students to see the Brazilian's public health reality, differing from what is seen in the classroom, inciting to the students, the creativity in front of adversities and restrictions frequently found on the centers responsible for the region's public health.

From the realities found, the environment provokes the advent and growth of the student's critical sense when confronting several needs, not only on the city's government scope but also on federal scope, which demands from the student, skills and critical analysis, so they can implement cohesive actions for each situation. Therefore, the student must be stimulated on his formation by using the experience from fields of research and extension, that are used tools in the formation process.

\section{Discussion}

With the frequent changes on the patient's health care field, and the several assistance tools, the health professional is driven, increasingly, to seek their development, improvement and a good domain of intellectual, interpersonal and technique skills to accomplish clinical decisions with effectivity. Consequently, not only considering the professional scope, but also the development of practical activities, during graduation, the clinical reasoning is highlighted as a tool that provides the acquisition of clinical and analytical skills, reflecting in favorable results [11].
About the nurse's competencies as a professional, the clinical reasoning practice interfere directly upon the given assistance's quality, bearing in mind that such practice guides the information gathering, orients the observation of the data gathered, supports the implemented decisions and corroborates for the evolution and evaluation of the nursing care planning [11-12].

The critical thinking practice promotes the development of capabilities such as: observation, analysis, review, autonomy of thought and ideas, expansion of their horizons and interaction with the reality, so, it characterizes itself as a skill that must be acquired, and is not associated with intelligence [12].

With this, such capabilities allow the nurse to break away from the technicist logic with emphasis on the knowledge and the know - how, assuring to the professional an active role in the care process, in addition of the category's empowerment. By developing such skill, the student comes across a different way to apply the learned and discussed theory in class, which results on an improvement of the intellectual, interpersonal and technical knowledge, to make good clinical decision accordingly to a safe practice, and capable to produce desirable health results [13].

So, some authors defend that the learning activities from concepts results in a positive influence on the clinical reasoning development, as well as reported that experiences of education - apprenticeship have the same effect, being some of them: the use of mobile technology on clinical practices; the education and the practice of research critical evaluation as an opportunity to develop skills that can also be used on clinical and critical reasoning; the experience of a debate structured and mediated by the professor, creating the opportunity for the students to explore different care perspectives on the decision taking in questions related to the nursing care; use of the mental mapping strategy on the development of clinical reasoning skills during the patient's care planning; and the clinical 
emergency simulations to develop such skill [1, 2, 14].

For example, Australian researchers, made a virtual game so the nursing students could learn about the nursing practice, using virtual situations, and thus the decision taking was analyzed using determined conditions [15]. Furthermore, authors corroborated that the clinical reasoning is present on all assistance actions and decisions of the nurse: phenomenon's diagnosis, in the choice of appropriated interventions and in the evaluation of obtained results. The diagnostic's formulation contains the expectations of interventions and possible results, on a given context, and depends on the involved people (nurse, patient, relative, community) and on the relationships that are stablished between people [16].

This way, one notices that on most of the studies found, the teaching practices were targeted to the new methodology types, uttered as active, the purpose is to incite the student to develop skills that will be applied on his professional routine. Furthermore, one notices that the clinical experience corroborates to complement the nursing student's formation process, so they may obtain abilities and skills accordingly to nursing's assistance practice and can accomplish the process in a safe way, thus, avoiding cases of clinical iatrogenic [17].

\section{Conclusion}

The experience lived by the nursing students characterized itself as a tool that amplifies and seizes the several abilities and skills that the nursing professional must have to give assistance on the most various scopes of the Unique Health System's attention network.

One notices that the constant improvement of clinical reasoning is a challenge for all Health professionals and demands the use of multiple strategies of permanent formation or, continuous, with common purposes and goals, and that makes use of the systemic practices on several assistance fields, being public or private.

Considering the need to value several knowledge standards and teaching styles, the upgrade programs on this field must be planned and executed from a professional practice and from participant's experiences, aiming to offer opportunities to change abilities, knowledge and behaviors, on its own work place.

Facing this, the concretization and disclosure of this and others studies related to the discussed theme may subsidize nursing professionals regarding elaboration and implementation of scientific, human and holistic nursing's practices. Managing to them, the reflections about the practice on the scopes of education, research and extension.

\section{References}

1. Lai $C Y$, Wu CC. Supporting nursing students' critical thinking with a mobile web learning environment. Nurse Educ. 2012;37(6):235-6.

2. Simmons B. Clinical reasoning: concept analysis. J AdvNur. 2010;66(5):1151-8.

3. Alfaro-Lefevre R. Aplicação do processo de enfermagem: uma ferramenta para o pensamento crítico. 8. ed. Porto Alegre: Artmed; 2014

4. Menezes SSC, Corrêa CG, Silva RCG, Cruz DAML. Clinical reasoning in undergraduate nursing education: a scoping review. Rev Esc Enferm USP • 2015; 49(6):1037-44

5. Pereira AH, Diogo RCS. Analysis of clinical thinking of majoring in Nursing in implementing the systematization of nursing care. J Health Sci Inst. 2012;30(4):349-53.

6. Cerullo JASB, Cruz DALM. Clinical Reasoning and Critical Thinking. Rev Latino-Am Enfermagem. 2010; 18(1): [06 telas].

7. Bittencourt GKGD, Crossetti MGO. Habilidades de pensamento crítico no processo diagnóstico em enfermagem. Rev Esc Enferm USP. 2013; 47(2):341-7.

8. Minayo CS. Pesquisa social: teoria, método e criatividade. $26^{\mathrm{a}}$ ed. Petrópolis: Vozes; 2007.

9. Ministério da Saúde (BR). Secretaria de Atenção a Saúde. Departamento de Atenção Especializada. Manual Instrutivo da Rede da Atenção as Urgências e Emergências no Sistema único de Saúde (SUS). Brasília: Editora do Ministério da Saúde; 2013.

10. Padilha, R.G; Vattimo, M.F.F;Silva, S.C; Kimura, M. Enfermagem em UTI: cuidado do paciente critico. Barueri; Mamole, 2010. 
11. Bittencourt GKGD, Crossetti MGO. Habilidades de pensamento crítico no processo diagnóstico em enfermagem. In: Proceedings of the Latin American Symposium; 2011; São Paulo, Brasil. São Paulo: NANDA International; 2011. p. 61.

12. Chang MJ, Chang YJ, Kuo SH, Yang YH, Chou FH. Relationships between critical thinking ability and nursing competence in clinical nurses. J Clin Nurs. 2011;20(21-22):3224-32.

13. Kaddoura MA. Eff ect of the essentials of critical care orientation (ECCO) program on the development of nurse's critical thinking skills. J Cont Educ Nurs. 2010;41(9):424-32.

14. Lunney M. Levantamento de dados, julgamento clínico e diagnósticos de enfermagem: como determinar diagnósticos precisos. In: Diagnósticos de Enfermagem da NANDA: definições e classificação 2009-2011. Porto Alegre: Artmed; 2011.

15. Johnsen HM, Fossum M, Vivekananda-Schmidt P, Fruhling $A$, Slettebø A. A Serious Game for Teaching Nursing Students Clinical Reasoning and Decision-Making Skills. Stud Health Technol Inform. 2016;225:905-6

16. O'Neil ES, Dluhy NC. Modelling novice clinical reasoning for a computerized decision support system. J Adv Nurs. 2005;49(1):68-77.

17. Lunney M. Pensamento crítico para o alcance de resultados positivos em saúde: análises e estudos de casos em enfermagem. Porto Alegre: Artmed; 2011.

Publish in International Archives of Medicine

International Archives of Medicine is an open access journal publishing articles encompassing all aspects of medical science and clinical practice. IAM is considered a megajournal with independent sections on all areas of medicine. IAM is a really international journal with authors and board members from all around the world. The journal is widely indexed and classified Q2 in category Medicine. 